6. Shakespeare and Language

Jonathan Hope

When Shakespeare and his contemporaries thought about language, they thought of speech: breathy, ephemeral sounds cast into the air. This very ethereality was taken as a proof of one of the key Renaissance ideas about language: in as much as it allowed humans to make evident their ability to reason, it was a divine gift, distinguishing humanity from, and elevating it above, the rest of creation. The gift of language could raise the monstrous to the level of the human, as it does Caliban, and the voluntary abandonment of language suggested a descent: as when the arrogant Ajax, swollen with pride at the prospect of single combat with Hector, loses his ability to distinguish social rank, along with his humanity, to a mumbling silence:

THERSITES The man's undone for ever, for if Hector break not his neck i'th' combat he'll break't himself in vainglory. He knows not me. I said, 'Good morrow, Ajax', and he replies, 'Thanks, Agamemnon'. What think you of this man that takes me for the General? He's grown a very land-fish, languageless, a monster.... he'll answer nobody. He professes not answering. Speaking is for beggars. [...] He wears his tongue in's arms. (Troilus and Cressida 3.3.249-60)

Language is social in the Renaissance in a formal, public sense we no longer quite appreciate: there is a clear link here between Ajax's loss of language and his mistaking 
the lowly Thersites for the highest of the Greek generals. His loss of language is not complete: Ajax can still manage a dismissive 'Thanks, Agamemnon', and he can proudly declare that speaking is for beggars - but he has lost his reason, and therefore his membership of society. He is instead its laughing-stock.

In Romeo and Juliet, we see the reverse journey. The play begins with Romeo, conventionally moping, in love with Rosaline, while Mercutio seeks him out, mocking the halting language of the stereotypical lover:

Romeo! Humours! Madman! Passion! Lover!

Appear thou in the likeness of a sigh.

Speak but one rhyme and I am satisfied.

Cry but 'Aye me!' Pronounce but 'love' and 'dove'.

Speak to my gossip Venus one fair word. (2.01.7-11)

Romeo avoids his friend, lurking silently off-stage, coming forward only when Mercutio departs - and the next time they meet, Romeo has fallen for Juliet, and the authenticity of this love recharges his social and linguistic energy:

MERCUTIO You gave us the counterfeit fairly last night.

ROMEO Good morrow to you both. What counterfeit did I give you?

MERCUTIO The slip, sir, the slip. Can you not conceive? 
ROMEO Pardon, good Mercutio. My business was great, and in such a case as mine a man may strain courtesy. $(2 \cdot 3 \cdot 40-5)$

Here, the two indulge in a passage of wordplay: Mercutio begins, proleptically substituting 'counterfeit' for 'slip', a term for a counterfeit coin. Romeo is slow to pick up on this at first, hence Mercutio's explanation, but he neatly plays on Mercutio's 'conceive' with his 'great' business ('great' being a synonym for 'pregnant'), and there is also an obscene meaning of 'case', which could refer to the vagina. So on the surface, Romeo says, 'Sorry, Mercutio, but my business was important, and in those circumstances it is allowable to be impolite' - but a possible second meaning is, 'You should have seen the woman I was with last night!'.

This quick interplay of polysemy is typical of much discourse in Shakespeare, and has, as we will see, sometimes irritated Shakespeare's later critics, but it is important that we recognise (however obscure or laboured we now find the humour), that wordplay like this was a sign of intelligence and social engagement in the Renaissance - as Mercutio goes on to say.

Why, is not this better now than groaning for love? Now art thou sociable, now art thou Romeo, now art thou what thou art, by art as well as by nature, for this drivelling love is like a great natural. (2.3.76-9) 
Romeo has regained his language, and has become 'sociable' again - fit for society - and he does this by demonstrating 'art' (the artificial control of language) through a series of puns we now find excruciating (for example, 'O single-soled jest, solely singular for the singleness!' [2.3.57]). Mercutio's values are (for us) unexpected: 'nature' is associated with simplicity (a 'drivelling... natural', or simpleton). The Renaissance inherited from the classical rhetorical tradition a radically different approach to creativity from our own: as Mercutio implies, 'art' (or craft) is what distinguishes the educated, rational being, from the 'natural' accident. Language should be consciously manipulated: creativity is to be controlled by learned rhetorical practice. ${ }^{1}$ To the Renaissance, creativity without years of studied craft, learning tropes and figures, consciously channelling the products of imagination by art, was literally nothing - it produced the empty nonsense of the moping Romeo. Similarly, in Hamlet, Ophelia's madness produces an outpouring of unconstrained language:

She speaks much of her father, says she hears

There's tricks i'th' world, and hems, and beats her heart, Spurns enviously at straws, speaks things in doubt

That carry but half sense. Her speech is nothing, Yet the unshapèd use of it doth move The hearers to collection. They aim at it, And botch the words up fit to their own thoughts, Which, as her winks and nods and gestures yield them, 
Indeed would make one think there might be thought, Though nothing sure, yet much unhappily. (4.5.4-13)

Ophelia talks of her murdered father, Polonius, suggests there are plots ('tricks') afoot, stumbles over her words ('hems'), makes the gestures associated with grief and distraction, is suspicious of harmless things ('Spurns... at straws'), says things which cannot be understood or which have no clear sense ('things in doubt/ ...carry but half sense'). The absence of conjunctions in this report ('She speaks [...] says [...] Spurns [...] speaks $[\ldots . .$.$] ') mimics the confused, 'unshaped' nature of her speech; 'unshaped' carries a$ particular force here, and in the Renaissance generally, where the craft of oral performance was the focus of almost the entire educational system. Ophelia's madness causes her to lose control of language - to lose the ability to structure discourse under the control of reason. While for the Romantics such a loss of constraint might have been seen as liberating, offering the possibility of insight beyond the everyday, for the Renaissance it represented the potential triumph of the forces of chaos over the order imposed by man's rational intellect. As the report goes on to suggest, unregulated expression is a dangerous force, liable to introduce error and confusion into the world. Ophelia's 'unshaped' language makes those who hear it attempt to reconstruct its lost meaning ('botch the words up'), but their conjectures are uncertain ('nothing sure') and dark.

This prizing of artifice in language, the stress on display of craft and formal learning, is almost entirely alien to us, and results in many of our difficulties with Shakespeare's 
texts (especially his wordplay) - indeed, it is a far greater block to understanding Shakespeare's language than the relatively minor changes in semantics and grammar that have occurred since the seventeenth century. Complaints about Shakespeare's puns enter the critical tradition in the eighteenth century - Samuel Johnson complained that 'a quibble, poor and barren as it is, gave [Shakespeare] such delight, that he was content to purchase it, by the sacrifice of reason, propriety and truth.' Subsequent critics, even as late as the twentieth century, have been made uneasy by the apparently arbitrary nature of puns. $^{2}$ Such hostility to wordplay is, however, relatively rare before the eighteenth century. Miriam Joseph traces the history of critical valuations:

$[\mathrm{T}] \mathrm{o}$ play upon the various meanings of a word represented an intellectual exercise, a witty analysis commended and relished by Aristotle, practiced by Plato and by the great dramatists of Greece, esteemed and used by Cicero, employed by medieval and Renaissance preachers in their sermons, regarded as a rhetorical ornament by the Elizabethans, but frequently despised as false or degenerate wit from the eighteenth century to the present day.

Only a small number of other critics have followed Joseph in arguing for a serious approach to wordplay. ${ }^{3}$ Joseph's account lays out the complexity of classical approaches to wordplay, and gives a sense of the range of effects Shakespeare and his characters could generate: ${ }^{4}$

Antanaclasis 'a figure which in repeating a word shifts from one of its meanings to 
another':

To England will I steal, and there I'll steal.

(Henry V 5.01.78)

Syllepsis - a figure also involving one word with more than one meaning, distinguished from antanaclasis by the fact that the word appears only once, with both meanings brought simultaneously into play:

hang no more about me, I am no gibbet for you

(Merry Wives of Windsor 2.02.16-7)

Paronomasia like antanaclasis, this involves two iterations, but, crucially, in paronomasia the words are not pure homophones:

Out, sword, and to a sore purpose! $\quad$ (Cymbeline 4.01.19)

Asteismus - a deliberate shifting of sense by a second speaker:

CLOTEN Would he had been one of my rank!

SECOND LORD [aside] To have smelled like a fool. (Cymbeline 2.01.13-5)

This four-fold analysis of wordplay is rather more complex than the definition of a pun offered by Addison in the early eighteenth century: ${ }^{5}$ 
1711 Addison, Spectator 61: 'Having pursued the History of a Punn... I shall here define it to be a Conceit arising from the use of two Words that agree in Sound but differ in Sense.'

and this goes some way to explaining post-seventeenth century hostility to wordplay. Enlightenment critics saw puns as involving two words brought together by a trivial and arbitrary resemblance of form (hence Addison's 'two Words that agree in Sound but differ in sense') - but, as Margreta de Grazia has argued, before dictionaries established fixed spellings and associated particular meanings with particular spellings of words, it is possible that speakers of a language would not have identified the 'words' associated with each meaning as being distinct entities. ${ }^{6}$ Addison's model of a 'word' presupposes the ideal of one sense to one form. He clearly assumes that, where there are two senses, but apparently one form, we must be dealing with a case of two superficially identical, but actually different, words. This ideal, of one form to one sense, is what dictionaries bring to the language: the spellings dye/die are separated into two stable, distinct forms only by orthographic standardisation. The 'two' words are created and maintained by orthographic standardisation - before dictionaries were available, there was no stable basis on which to identify variant spellings like dye/die or corse/coarse/ course/cours/cors as anything other than multiple possible realisations of a single 'word', which has a range of possible meanings.

Puns thus have value for Renaissance users of language, because their production and 
recognition involve the active use of the linguistic system, and demonstrate a facility with it prized in the rhetorical tradition. To recognise wordplay, a speaker has to bring into play two or more possible meanings associated with one word, producing an aesthetic effect of complexity. The Renaissance audience is involved in actively maintaining the double play of meaning, but the post-Enlightenment audience is a passive observer of what appear to be merely facile and arbitrary similarities of form. This allows us to begin to appreciate what Shakespeare might have perceived in these apparently 'barren' interplays of wit.

As we have seen, language was central to the notion of the human in the Renaissance. But this did not mean that all languages were equally regarded. The prestige of classical rhetorical culture and continental European learning meant that for some commentators, English was a 'base', undeveloped language. Scholars such as Richard Mulcaster advocated the deliberate expansion of English through the borrowing of words which would enable its users to talk, and write, on more sophisticated topics. There was much contemporary comment on such borrowings: on the one hand, new words were held to enrich the language by expanding its resources and stylistic potential; on the other, the often Latinate terms were sometimes felt to be overly scholarly ('Inkhorn' as contemporary writers had it) because such words were obscure to most speakers of English. Those who had a classical education could be expected to understand and be impressed by words borrowed from Latin, as Shallow is when he works out what Bardolph means by the newly coined 'accommodated' in 2 Henry IV: 
'Better accommodated' - it is good; yea, indeed is it. Good phrases are surely, and ever were, very commendable. 'Accommodated' - it comes of 'accommodo'. Very good, a good phrase. (3.2.64-6)

Bardolph's response to Shallow's praise is surprisingly defensive, however:

Pardon, sir, I have heard the word - 'phrase' call you it? - By this day, I know not the phrase; but I will maintain the word with my sword to be a soldier-like word, and a word of exceeding good command, by heaven. (3.2.67-70)

His defence of 'accommodated' as a 'soldier-like' word suggests that he suspects that Shallow is accusing him of linguistic pretension in using Latinate words. Although there is no reason to doubt the genuine nature of Shallow's praise, the source of Bardolph's linguistic insecurity becomes clear when he attempts to give his own definition of 'accommodated'. He has no idea of what this fashionable word means, and can only offer a confused and circular, definition:

'Accommodated'; that is, when a man is, as they say, accommodated; or when a man is being whereby a may be thought to be accommodated; which is an excellent thing. (3.2.70-3) 
If aspirational speakers were sometimes caught out over-reaching, 'ordinary' speakers could also offer wry comment on the stylistic pretensions of Latinate English. In Love's Labour's Lost, the knight Armado pays Costard to deliver a letter for him, saying, as he hands over the money, 'There is remuneration' (3.1.120). Left alone on stage, Costard tallies his fee: 'Now will I look to his remuneration. Remuneration- O, that's the Latin word for three-farthings' (3.1.125-126). Faced with an audience which would have included the equivalents of Shallow, capable of identifying the Latin root of newly borrowed words, and a large group of Costards, able to spot a Latin word, but dependent on hearing it in context to derive a meaning, Shakespeare developed a self-glossing style, deftly mixing borrowed and native English terms:

for cogitation

Resides not in that man that does not think (The Winter's Tale 1.2.273-4)

$\mathrm{O}$, matter and impertinency mixed!

Reason in madness! (King Lear 4.6.168-9)

By all your vows of love, and that great vow

Which did incorporate and make us one. (Julius Caesar 2.01.271-2)

As Bardolph's example shows, Shakespeare was well aware of the dangers of borrowing - and, perhaps contrary to the popular notion of Shakespeare as the supreme coiner of words, the plays are full of characters who are satirised either for the outright misuse of 
the new Latinate vocabulary (Dogberry in Much Ado About Nothing, Quickly in the Henry IV plays, Henry V and Merry Wives, Dull in Love's Labour's Lost), or for putting on more general, often courtly, linguistic airs (Osric in Hamlet, Oswald in King Lear, Armado and Holofernes in Love's Labour's Lost). Statistical studies show that Shakespeare employs less Latinate vocabulary than do his contemporaries and, as Daniel points out in his Arden edition of Julius Caesar, Shakespeare gives the suspect Cassius a vocabulary of new words and the noble Brutus one of old ones- Iago too is keen on 'fire new' words. ${ }^{7}$

While Renaissance authors consciously expanded English vocabulary by borrowing from Latin and other languages, such borrowings were numerically less important than derivation, or the creation of new words from existing resources. Shakespeare makes particular use of the processes of affixation (changing the role or meaning of a word by adding morphemes to the start or end) and conversion (shifting the grammatical role of a word without any necessary change in the morphology). For example, Lear takes the fashionable borrowing 'accommodated', used, as we have seen, satirically in 2 Henry IV, and turns it into a serious element of his discourse on the fragility of humanity by adding the English prefix 'un-': 'unaccommodated man is no more but such a poor, bare, forked animal as thou art' (King Lear 3.4.98-100). Shakespeare seems particularly drawn to 'un' as a way of negating concepts, perhaps because it suggests an active process of undoing something, rather than simple absence. It crops up in the linguistically self-conscious display of Holofernes: 'his undressed, unpolished, uneducated, unpruned, untrained, or 
rather unlettered, or ratherest unconfirmed, fashion' (Love's Labour's Lost 4.2.15-17). Even when not motivated by character, one use can often set up a string of further uses:

Haply that name of chaste unhapp'ly set

This bateless edge on his keen appetite, When Collatine unwisely did not let

To praise the clear unmatchèd red and white (The Rape of Lucrece 8-11)

This passage is then followed quickly by 'unlocked' (16); 'unknown' (34); 'untimely' (line 43).

Shakespeare's attraction to linguistic forms that express activity can also be seen in his fondness for the agentive '-er' suffix. In contrast to 'un-', this suffix is not found throughout his work, but its use is marked in Antony and Cleopatra, where '-er' is frequently added to verbs to produce a noun with the meaning 'one who does [verb]'. When the defeated Antony returns from battle to find Cleopatra allowing Caesar's messenger to kiss her hand, he first rails at her for deigning to look on 'feeders' (3.13.109), and when she tries to justify her actions, he persists: 'You have been a boggler ever' (3.13.111). Here 'feeder' means a servant, one who is fed (by his master), and 'boggler' means one who starts with fright ('You boggle shrewdly; every feather starts you' All's Well That Ends Well, 5.3.235) and/or quibbles with words. Either sense (or both) could work here, since Antony's defeat is prompted by Cleopatra's flight from the battle, while her entertaining Caesar's messenger could be interpreted as 
equivocation. 'Feeder' is relatively common in this sense in the early modern period, but 'boggler' appears to be unique. Later in the same scene, there is another rare '-er' formation, as Antony calls Cleopatra's hand a 'plighter' (3.13.127). The play employs several relatively established '-er' forms, such as 'surfeiter' (2.1.33), 'wearer' (2.2.7), 'reporter' (2.2.194) and 'master-leaver' (4.10.22), which occur elsewhere in Renaissance literature, but, as with 'boggler' and 'plighter', there are others which are unique, or for which Shakespeare himself is the only repeat user in the period: 'strangler' (2.6.119), 'breather' (3.3.21), and 'sworder' (3.13.30).

While Antony and Cleopatra is marked out by the frequency of '-er' forms it contains, they also cluster around descriptions of Antony in Julius Caesar:

CASSIUS A peevish schoolboy, worthless of such honour, Joined with a masquer and a reveller!

ANTONY Old Cassius still. (5.1.61-3)

Shakespeare's grammar (or more correctly, morphosyntax - the system of grmmatical relations between words and the inflections that mark them) does not differ greatly from our own. The most significant difference is contextual, in that he wrote at a time when written English was in the process of standardising. This meant that Shakespeare had a wider range of morphosyntactic options open to him than we do today. Whenever he wrote a question or a negative, for example, Shakespeare might have followed the now standard pattern, and use the auxiliary verb 'do': 'What do these fellows mean? Don't 
they know Achilles?' Alternatively, as he actually did in this case, he could use a much older system, slowly disappearing from the language, which reversed the subject and verb: 'What mean these fellows? Know they not Achilles?' (Troilus and Cressida 3.3.64) The system without 'do' was increasingly sounding old-fashioned to those younger than Shakespeare, and can sometimes be seen to pattern stylistically with formal contexts. Shakespeare's fondness for it, compared with that of younger writers like Fletcher and Middleton, may be one of the reasons the Restoration found Shakespeare somewhat dated; it may also have licensed adaptation of his plays, rather than straight revival. Other areas of choice included the formation of relative clauses, where the constraints governing the use of the relative pronouns were not as restrictive as they now are in standard English: 'Here is a sick man that would speak with you' (Julius Caesar, 2.1.309). Most writers now would avoid the use of 'that' with a human antecedent as here. Conversely, Early Modern English allowed the use of 'who' with non-humans: 'Against the Capitol I met a lion / Who glazed upon me' (Julius Caesar, 1.3.20-1). Shakespeare could also use zero pronouns in subject position, something confined to speech today: 'Let him that will a screech-owl aye be called / Go into Troy and say their Hector's dead. / There is a word will Priam turn to stone' (Troilus and Cressida 5.11.16-18). That is, 'There is a word which will turn Priam to stone'.

Because these choices were disappearing from standard written English - along with others, such as the '-eth' ending on third person singular present tense verbs ('goeth'), the use of 'thou', and subjunctives - they quickly become associated with older speakers and formal situations. Shakespeare was born just early enough in the sixteenth century, and 
far enough away from the centre of linguistic innovation in the south east, that he retained a more ready access to these disappearing linguistic features than did most of his contemporaries, and all of the generation of writers who followed him.

While the choices available to Shakespeare at the level of morphosyntax rarely cause problems for us in reading his texts, one feature that does make it difficult for many people initially is his often highly unusual word order. The normal order for elements in English clauses is Subject - Verb - X (where $\mathrm{X}$ stands for a variety of possible entities, most frequently object, complement, or adverbial), as in these three consecutive clauses from Claudius: 'O, my offence is rank! It smells to heaven. / It hath the primal eldest curse upon't' (Hamlet 3.3.36-7). But Shakespeare frequently inverts or disrupts the expected order of elements in a clause, sometimes in order to bring the most salient word to the front, as happens in the very next clause in Claudius' speech: 'Pray can I not' (Hamlet 3.3.38), that is, 'I can not pray'. Clauses are similarly inverted in the parallel syntax of this exchange from Troilus and Cressida:

ACHILLES

I have strong reasons.

\section{Of this my privacy}

I have strong reasons.

ULYSSES

But 'gainst your privacy

The reasons are more potent and heroical. (3.03.184-7)

Here, in each case a final adverbial is brought to the front of the clause. Disruption can also involve movement within the clause, as in, 'Let him that will a screech-owl aye be 
call'd, / Go in to Troy, and say there, Hector's dead,' where the complement ('screechowl') is moved in front of the main verb. Often these disruptions are for emphasis, but they can also function to shift words around in the line so that the metrical template is met. Compare this line and a half as it appears in Antony and Cleopatra with the more 'normal' word order: 'With news the time's in labour, and throws forth / Each minute some' (3.7.80-1), as opposed to, 'The time's in labour with news and each minute throws some forth.' The 'normal' version has the content noun 'news' in an unstressed position, and has an extra unstressed syllable at the end of the first line - not fatally unmetrical, given Shakespeare's practice elsewhere, but perhaps clumsy enough when combined with the flatness of the 'normal' version to prompt a rewrite to the less expected one. Here we see perhaps the real key to Shakespeare's variation on word order: an unexpected order can freshen otherwise mundane language, forcing the hearer to work harder, and producing a pleasing aesthetic effect of complexity.

This brings us naturally on to Shakespeare's use of verse forms. He writes most often in blank verse - unrhymed iambic pentameter - but he also makes extensive use of the sonnet form (fourteen lines of rhymed iambic pentameter), and on occasion other stanzaic forms, all still employing iambic pentameter (six-line stanzas rhyming ababcc for Venus and Adonis; seven-line stanzas rhyming ababbcc for Lucrece). He breaks with iambic pentameter for songs, and the enigmatic lyric 'The Phoenix and the Turtle', which uses a trochaic form (initially, seven-syllable, four-stressed lines, in stanzas of four lines rhyming abba, shifting to three-line stanzas rhyming aaa). 
The most detailed and subtle account of Shakespeare's iambic pentameter is George Wright's Shakespeare's Metrical Art, though beginners may at first find confusing the fact that most of his discussion is of Shakespeare's complex variations on the basic iambic pattern. ${ }^{8}$ That basic pattern consists of a metrical template which controls the number of syllables allowed in a line (ten), and the positions in the line where stressed syllables are allowed to appear (only in even numbered slots):

\begin{tabular}{|l|l|l|l|l|l|l|l|l|l|}
\hline 1 & 2 & 3 & 4 & 5 & 6 & 7 & 8 & 9 & 10 \\
\hline & [stress] & & [stress] & & [stress] & & [stress] & & [stress] \\
\hline
\end{tabular}

A key to avoiding confusion is the fact that the meter does not demand that every even position in any particular line has to have a stressed syllable: unstressed syllables can appear in even positions. The meter simply requires that, when a lexically stressed syllable is used, it must appear in an even position.

What is a lexically stressed syllable? Stress on English words is produced in two ways, depending on the nature of the word. If the word is polysyllabic, then the stress is fixed, and will always be the same, whenever the word is used (Shakespeare, for example, is always stressed on the first syllable, and attempting to stress it on the second will generally produce humorous effects). This is lexical stress. If a word is a monosyllable, however, stress is unfixed, and will depend on the context in which the word is used, and the whim of the speaker. It is perfectly possible to imagine several different ways of stressing monosyllabic clauses depending on the intended meaning: 
I gave it to him.

I gave it to him.

I gave it to him.

I gave it to him.

I gave it to him.

This optionality of stress on monosyllables in performance, coupled with the fact that iambic metre only seeks to determine the position of lexically stressed syllables, means that there is huge potential variation in the construction and performance, of iambic lines. For example, when Ulysses says of Cressida, 'There's language in her eye, her cheek, her lip' (Troilus and Cressida, 4.6.56), there is only one polysyllabic word in the line 'language' - which has two syllables, the first of which always carries stress ('language'). So the first syllable has to be placed in an even numbered position in the line - which it is:

\begin{tabular}{|l|l|l|l|l|l|l|l|l|l|}
\hline 1 & 2 & 3 & 4 & 5 & 6 & 7 & 8 & 9 & 10 \\
\hline There's & lan- & guage & in & her & eye & her & cheek & her & lip \\
\hline
\end{tabular}


The rest of the words are monosyllables, so the meter is not explicitly concerned with them: whether or not they carry stress will depend on the meaning and the sense that an actor wishes to convey, but note the way that the nouns 'eye', 'cheek', and 'lip' all appear in even positions: these content nouns are more likely to attract stress in performance than the pronoun 'her'. The most likely performance of this line would have an obligatory stress on 'lang-', then further optional stresses on 'eye', 'cheek, and 'lip'. Note too that although 'in' is placed in an even position, it is very unlikely to be given stress in performance - so there is a slight tension between the metical form (which might lead us to expect a stress here) and natural speech (which would very rarely have a stress on a preposition like 'in'). This tension between the norms of speech and the demands of the metrical form is the key to the sophistication of Shakespeare's iambic metre. Were he to follow the metrical template too closely by filling all the potentially stressed slots with stressed syllables, the verse would be mechanistic and tedious. Become too loose, however, and the tension between form and expression that raises poetry above prose would be lost. ${ }^{9}$

Theories of meaning (semantics) were much discussed in the Renaissance (particularly in regard to legal and theological matters), and the main positions were inherited from classical debates. Vivian Salmon cites as a typical summary of Renaissance theories of meaning the work of Juan Huarte, whose Examen de Ingenios (1575) was translated into English (from an Italian version) as The Examination of Men's Wits (1594). ${ }^{10}$ The principal question was, 'From where do words derive their meaning?'. Huarte identifies two competing positions on this, which he associates respectively with Plato and 
Aristotle (he calls the debate 'a question much hammered between Plato \& Aristotle' [p. 117]).

The 'Platonic' position, voiced by the characters of Cratylus and Socrates in Plato's Cratylus, is that there is, or should be, a 'natural' relationship between a word and its referent - that words derive their meaning from a non-arbitrary connection to the thing named. The 'true' name for something is thus mystically linked to, and expresses, the essence of the thing named - as Huarte has it, 'there are proper names, which by their nature carrie signification of things, and [...] much wit is requisite to deuise them' (p. 118). That is, names are 'proper' in the sense of being naturally linked to the thing they refer to, and 'much wit' is required to devise such names, since the namer must understand the nature of things in order to be able to name them correctly. The standard Renaissance example of such a process was Adam's naming of the animals:

And this opinion is fauoured by the diuine scripture, which affirmeth that Adam gaue euerie of those things which God set before him, the proper name that best was fitting for them (p. 118)

Hence this is sometimes referred to as the 'Adamic' theory of meaning.

The alternative position, best known from Aristotle's On Interpretation, stressed the conventional nature of meaning: words have meaning because of the way they are used ('custom', as many writers have it), and through their relationships with each other. 
Under this theory, names are arbitrary, and Huarte claims that this can be shown by cross-linguistic comparison:

Aristotle will not grant, that in any toung there can be found any name, or manner of speech, which can signifie ought of it own nature, for that all names are deuised and shaped after the conceit of men. Whence we see by experience, that wine hath aboue 60 . names, and bread as manie, in euerie language his, $\&$ of none we can auouch that the same is naturall and agreeable thereunto, for then in all the world would vse but that. (p. 118)

If the Platonic theory were correct, Huarte argues, the terms for such staples as 'wine' and 'bread' would be the same in all languages - since the nature of these things does not change between languages. The fact that names change between languages shows that they are conventional and arbitrary, rather than linked to the essential nature of the thing to which they refer.

'Custom' is recognised by many Renaissance writers as the governing force in meaning, and the best guide to usage: Juliet, when she muses on Romeo's name, and notes that 'That which we call a rose / By any other word would smell as sweet' (2.1.85-6), reveals herself to be an Aristotelian. But the strange links that could be established by wordplay, indeed even by Shakespeare's punning on his own name, and 'will' in the Sonnets (135, 136), remind us that the occult attraction of the Adamic theory ran deep, even as Renaissance writers attempted to explain them rationally[?] 
Notes

1 See Brian Vickers, Classical Rhetoric in English Poetry (London: Macmillan, 1970).

2 Samuel Johnson, 'Preface to Shakespeare' from The Plays of William Shakespeare (1765). For Coleridge, see T. M. Raysor (ed.), inc. S.T. Coleridge:

Shakespearean Criticism (London: Dent, 1960) vol. 1, p. 86; the discussion in Keir Elam, Shakespeare's Universe of Discourse: language games in the Comedies (Cambridge: Cambridge University Press, 1984), pp. 1-6. For Stephen Booth, see Booth, 'Exit, Pursued by a Gentleman Born,' in Wendell M. Aycock, ed., Shakespeare's Art from a Comparative Perspective, Proceedings: Comparative Literature Symposium (Lubbock, TX: Texas Technical University, 1981), vol. 12, pp. 51-66; and Booth, 'Shakespeare’s Language and the Language of Shakespeare's Time', Shakespeare Survey 50 (1997), pp. $1-17$.

3 Miriam Joseph, Shakespeare's Use of the Arts of Language (New York: Columbia University Press, 1947), especially pp. 165-71. For further favourable assessments of Shakespeare's wordplay, see Molly Mahood, Shakespeare’s Wordplay (London: Methuen, 1957); various authors, 'M.M. Mahood, Shakespeare’s Wordplay - Some Reappraisals' in Connotations 6.1 (1996-7) pp. 1-45; Patricia Parker, Shakespeare from the Margins: Language, Culture, Context (Chicago: University of Chicago Press, 1996); Russ MacDonald, The Bedford Companion to Shakespeare (New York: Bedford/St. 
Martin's, 2001), p. 44; and MacDonald, Shakespeare and the Arts of Language (Oxford: Oxford University Press, 2001), ch. 7. Two general approaches to puns and wordplay are: Walter Redfern, Puns (Oxford: Blackwell, 1984), and Jonathan Culler, ed., On Puns: the foundation of letters (Oxford: Blackwell, 1988).

4 Joseph, 165.

$5 \quad$ Quoted here from the OED, 'pun'.

6 Margreta de Grazia, 'Homonyms before and after lexical standardisation', Deutsche Shakespeare-Gesellschaft West Jahrbuch (1990), pp.143-56.

7 David Daniel, ed., Julius Caesar (London: The Arden Shakespeare, 1998), pp. $60-2$.

8 George T. Wright, Shakespeare's Metrical Art (California: University of California Press, 1998).

9 Wright carries these arguments much further - see op. cit. p. 259ff. Note that for the sake of clarity I have omitted mention of two common irregularities in Shakespeare's iambic metre: (1) the first position in a line can sometimes hold a stressed syllable (trochaic inversion): 'Speaking in deeds and deedless in his tongue' (Troilus and Cressida 4.6.101); (2) an unstressed eleventh syllable is sometimes allowed (this becomes more frequent over Shakespeare's career, and has been used to date the plays): 'Yet gives he not till judgement guide his bounty' (Troilus and Cressida 4.6.105). 10 Vivian Salmon, 'Views on meaning in Sixteenth-Century England', in Language and Society in Early Modern England: Selected Essays (Amsterdam: John Benjamins, 1990), pp. 55-75. 
For Further Reading:

Sylvia Adamson et al., 2001, Reading Shakespeare's Dramatic Language (London: The Arden Shakespeare)

Catherine Alexander (ed.), 2004, Shakespeare and Language (Cambridge: Cambridge University Press).

Charles Barber, 1996. Early Modern English (Edinburgh: Edinburgh University Press)

Norman Blake, 2002, A Grammar of Shakespeare’s Language (Basingstoke: Palgrave)

Paula Blank, 1996, Broken English: Dialects and the Politics of Language in Renaissance Writings (London: Routledge)

David Crystal, 2008, 'Think on my Words': Exploring Shakespeare's Language (Cambridge: Cambridge University Press)

David Crystal, 2005, Pronouncing Shakespeare (Cambridge: Cambridge University Press)

E.J. Dobson, 1968 (2 ${ }^{\text {nd }}$ ed.), English Pronunciation 1500-1700 (2 vols Oxford: Clarendon Press)

Keir Elam, 1984, Shakespeare's Universe of Discourse: Language-games in the Comedies (Cambridge: Cambridge University Press)

Penelope Freedman, 2007, Power and Passion in Shakespeare's Pronouns: Interrogating 'you' and 'thou' (Aldershot: Ashgate)

Jonathan Hope, 2003, Shakespeare’s Grammar (London: The Arden Shakespeare).

John Porter Houston, 1988, Shakespearean Sentences: A Study in Style and Syntax (Baton Rouge: Louisiana State University Press)

Roger Lass (ed.), 1999, The Cambridge History of the English Language, vol. 3, 14761776 (Cambridge: Cambridge University Press)

Lynne Magnusson, 1999, Shakespeare and Social Dialogue: Dramatic Language and Elizabethan Letters (Cambridge: Cambridge University Press)

Terttu Nevalainen, 2006, An Introduction to Early Modern English (Edinburgh: Edinburgh University Press)

Vivian Salmon and Edwina Burness (eds), 1987, Reader in the Language of Shakespearean Drama (Amsterdam: John Benjamins) 
Brian Vickers, 1968, The Artistry of Shakespeare's Prose (London: Methuen)

George T. Wright, 1988, Shakespeare's Metrical Art (California: University of California Press) 